Pradeep Raj D and Irisappan Sarathchandiran. / International Journal of Research in Pharmaceutical and Nano Sciences. 9(1), 2020, 27-32.

Review Article

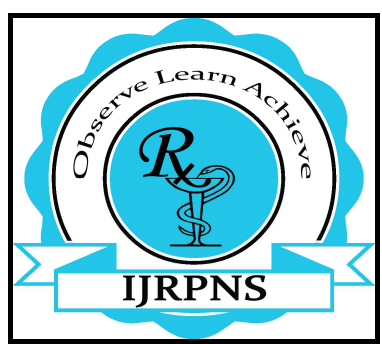

CODEN: IJRPJK

\section{International Journal of Research} in

Pharmaceutical and Nano Sciences

Journal homepage: www.ijprpns.com

https://doi.org/10.36673/IJRPNS.2020.v09.i01.A05
ISSN: $2319-9563$

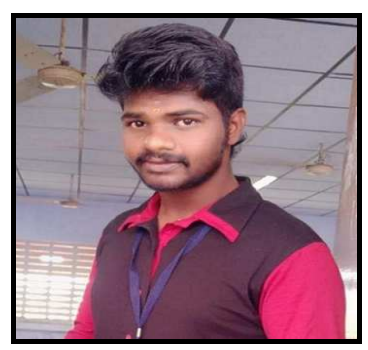

\title{
A REVIEW ON ANTIFERTILITY ACTIVITY OF MEDICINAL PLANTS
}

\section{Pradeep Raj*1 and Irisappan Sarathchandiran ${ }^{1}$}

${ }^{1 *}$ School of Pharmacy, Sri Balaji Vidyapeeth Deemed University, Pillayarkuppam, Puducherry, India.

\begin{abstract}
Medicinal plants are regular word which would everyone be able to mouth that is useful in treating numerous maladies which doesn't done by even allopathic medication. Among those the birth control at the same time increasing the fertility of human being are both become major problems in nowadays. This audit articles some short introduced refreshed data accumulated on logically demonstrated therapeutic plants utilized for against richness movement. This study provide information on name of the plants, family, parts used and therapeutic effects of medicinal plants have been reviewed for thorough research inclusive of Amaranthus, Acacia concinna, Adhatoda vasica, Alangium, Barleria prionitis, Butea monosperma, Cassis fistula, Carica papaya, Celastrus paniculatus, Daucus Carota, Flagellaria indica, Franseria artemisiodes, Hibiscus rosa-sinensis, Indigofera linnaei, Laurus nobilis, Nigella sativa, Olea europea, Papaver, Piper longum, Portulaca oleracea, Ricinus communis, Ruta graveolens, Salvia fruticosa, Taxus baccata, Trigonella foenum graecum, Valeriana Montana, Vitex negundo, Xanthium spinosum, Ziziphora tenuior, Zizyphus jujube, etc. This overview in reality demonstrates that it's time to make bigger upon experimental studies to source medicinal plants, plant extracts and their lively elements ought to be in addition investigated for their mechanisms. This review creates a strong foundation upon which to similarly examine the efficacy of plants which are both presently utilized by Female as traditional antifertility medicines, however also could be efficacious as an antifertility agent with extra research.
\end{abstract}

\section{KEYWORDS}

Anti-Fertility, Anti-implantation, Anti-Spermatogenic Activity and Contraceptive.

\section{Author for Correspondence:}

Pradeep Raj D,

School of Pharmacy,

Sri Balaji Vidyapeeth Deemed University,

Pillayarkuppam, Puducherry, India.

Email: pradeepraj2871@gmail.com

Available online: www.uptodateresearchpublication.com

\section{INTRODUCTION}

Antifertility agents are those which are capable of stopping ovulation or fertilization and able to result in termination of being pregnant ${ }^{1}$. Overpopulation is turning into one of the worldwide problems causing plenty have an impact on financial, social and natural assets ${ }^{2}$. The growth in population is alarming the growing world in the want for effective beginning control measures ${ }^{3}$. One of the

January - February 
serious issues in the growing nations like India is over populace and which might be extended approximately 9.2 billion by means of the year $2050^{4}$. Although a several synthetic contraceptive retailers are available these days, their use is related to intense aspect effects, inclusive of hormonal imbalance, high blood pressure, improved threat of most cancers and weight advantage ${ }^{5}$. Hence people are looking forward to the subculture of the use of herbal drug treatments, which have minimal and much less aspect results ${ }^{6}$. Medicinal plants are been the usage of form many centuries to treat each intellectual and physical contamination and to improve fitness of individuals, and about $80 \%$ of medical remedies are practicing with the aid of the growing nations ${ }^{7}$. However within the recent past tons interest has been shown to control regulation of fertility with the aid of the usage of medicinal flower ${ }^{8}$. Fertility regulation Despite of many medicinal flowers have been claimed to save you fertility, simplest few vegetation had been to this point been investigated for their antifertility pastime. Moreover the World Health Organization (WHO) has installation a venture force on plant research to discover new orally active non-steroidal contraceptive compounds ${ }^{10}$. Comprising birth control and management of infertility paperwork an important element of reproductive health ${ }^{9}$. Several plant extracts inhibit male and female fertility and may be evolved into contraceptives ${ }^{10}$.

\section{REPRODUCTIVE SYSTEMS}

The conceptive framework is a sex organ inside life form which works with the end goal of sexual propagation. Numerous non-living substances, for example, liquids, hormones, and pheromones are most significant types of gear for regenerative framework $^{11}$.

\section{Male Reproductive System}

The male conceptive framework comprises of various sex organs that assume a significant job during the time spent human generation. These organs are situated outwardly of the body and inside the pelvis. The primary male sex organs are the penis and the gonads which produce semen and sperm, which, as a major aspect of sexual intercourse, fertilize an ovum in the female's body; the fertilized ovum develops into a fetus, which is later born as an infant ${ }^{11}$.

\section{Female Reproductive System}

The female conceptive framework is comprised of inner and outside sex organ. It is working on the proliferation of new posterity. When the human female reproductive system is immature at birth and develops to maturity. Via puberty is able to produce gametes, and carry a fetus to full term. The internal sex organs are uterus, Fallopian tubes, and ovaries. The uterus or belly obliges are undeveloped organism which forms into fetus. Uterus additionally delivers vaginal and uterine discharges which help to travel of sperm to the Fallopian tubes. The ovaries produce the egg cells. The external sex organs are also known as genitals and vaginal opening. The vagina is connected to the uterus at the cervix ${ }^{11}$.

\section{ANTIFERTILITY}

Antifertility agents are those which are capable of stopping ovulation or fertilization and able to result in termination of being pregnant ${ }^{1}$. Drugs which used for stopping fertilization are called as antifertility effects. These are also called contraceptive effects. Contraception is the method of stopping normal manner of ovulation, fertilization and ovum implantation not anything but being pregnant ${ }^{12}$. 
Pradeep Raj D and Irisappan Sarathchandiran. / International Journal of Research in Pharmaceutical and Nano Sciences. 9(1), $2020,27-32$.

Table No.1: List of medicinal plants used for antifertility activity of male and female effects

\begin{tabular}{|c|c|c|c|c|c|}
\hline S.No & Name of the plant & Family & Part used & Medicinal activity & Reference \\
\hline 1 & Amaranthus viridis $L$. & Amaranthaceae & Roots & Contraception Activity & [13] \\
\hline 2 & Acacia concinna DC & Fabaceae & $\begin{array}{l}\text { Stem and } \\
\text { barks }\end{array}$ & $\begin{array}{l}\text { Spermicidal and semen } \\
\text { coagulating activities }\end{array}$ & [14] \\
\hline 3 & $\begin{array}{c}\text { Adhatoda vasica Nees Syn. } \\
\text { Justice adhatoda L. }\end{array}$ & Acanthaceae & Leaves & $\begin{array}{c}\text { Anti-implantation and } \\
\text { Abortifacient }\end{array}$ & {$[15],[16]$} \\
\hline 4 & Alangium Salvifolium (L.f.) & Alangiaceae & $\begin{array}{l}\text { Stems, } \\
\text { Barks }\end{array}$ & $\begin{array}{l}\text { Anti-implantation and } \\
\text { Abortifacient }\end{array}$ & {$[13]$} \\
\hline 5 & Barleria prionitis Linn. & Acanthaceae & Roots & Antifertility effect & [17] \\
\hline 6 & $\begin{array}{c}\text { Butea monosperma (Lam.) } \\
\text { Kuntze }\end{array}$ & Fabaceae & Seeds & Effects on testicular function & {$[18]$} \\
\hline 7 & Cassis fistula Linn. & Caesalpiniaceae & $\begin{array}{l}\text { Pods, } \\
\text { Seeds }\end{array}$ & Anti-oestrogenic activity & [19] \\
\hline 8 & Carica papaya Linn. & Caricaceae & Fruits & Anti-spermatogenic activity & {$[20]$} \\
\hline 9 & Celastrus paniculatus Willd. & Celastraceae & Seeds & Anti-spermatogenic action & {$[21]$} \\
\hline 10 & Daucus Carota Linn & Apiaceae & Seeds & $\begin{array}{c}\text { Blastocystotoxic and } \\
\text { Anti-implantaion effects, } \\
\text { Post-coital contraceptive effects }\end{array}$ & {$[22],[23]$} \\
\hline 11 & Flagellaria indica Linn. & Flagellariaceae & Leafs & Contraceptive & [24] \\
\hline 12 & $\begin{array}{l}\text { Franseria artemisiodes } \\
\text { Willd. }\end{array}$ & Asteraceae & $\begin{array}{l}\text { Whole } \\
\text { plants }\end{array}$ & Contraceptive & [25] \\
\hline 13 & Hibiscus rosa-sinensis Linn. & Malvaceae & Roots & $\begin{array}{l}\text { Anti-implantation and } \\
\text { Uterotropic activity }\end{array}$ & [26] \\
\hline 14 & Indigofera linnaei Ali & Fabaceae & Herbs & Anti-fertility activity & [27] \\
\hline 15 & Laurus nobilis Linn. & Lauraceae & Leafs & Testicular dysfunction & {$[28]$} \\
\hline 16 & Nigella sativa Linn. & Ranunculaceae & Seeds & Post-Coital Antifertility effect & [29] \\
\hline 17 & Olea europea Linn. & Oleaceae & Fruits & Contraceptive & {$[30]$} \\
\hline 18 & Papaver somniferum Linn. & Papaveraceae & Fruits & Induces Abortion & [13] \\
\hline 19 & Piper longum Linn. & Piperaceae & Fruits & Antifertility Activity & [31] \\
\hline 20 & Portulaca oleracea Linn. & Portulacaceae & Seeds & Impairement of Spermatogenesis & [32] \\
\hline 21 & Ricinus communis Linn. & Euphorbiaceae & Seeds & $\begin{array}{l}\text { Anti-implantation and } \\
\text { Abortifacient }\end{array}$ & [33] \\
\hline 22 & Ruta graveolens Linn. & Rutaceae & $\begin{array}{c}\text { Aerial parts } \\
\text { and Roots }\end{array}$ & Anticonceptive activity & [34] \\
\hline 23 & Salvia fruticosa Mill. & Labiatae & Leafs & Anti-implantation Effect & [35] \\
\hline 24 & Taxus baccata Linn. & Taxaceae & Leafs & Antifertility & {$[36]$} \\
\hline 25 & $\begin{array}{l}\text { Trigonella foenum graecum } \\
\text { Linn. }\end{array}$ & Fabaceae & Seeds & Antifertility activity & [37] \\
\hline 26 & Valeriana Montana Linn. & Valerianaceae & Roots & Sterilizer & [38] \\
\hline 27 & Vitex negundo L. & Lamiaceae & Seeds & Anti-Androgenic Effect & [39] \\
\hline 28 & Xanthium spinosum Linn. & Asteraceae & Leafs & Contraceptive & [40] \\
\hline 29 & Ziziphora tenuior Linn & Labiatae & Seeds & Emmenagogue & [41] \\
\hline 30 & Zizyphus juјuba Mill. & Rhamnaceae & Barks & Antifertility & [42] \\
\hline
\end{tabular}

Available online: www.uptodateresearchpublication.com January - February 


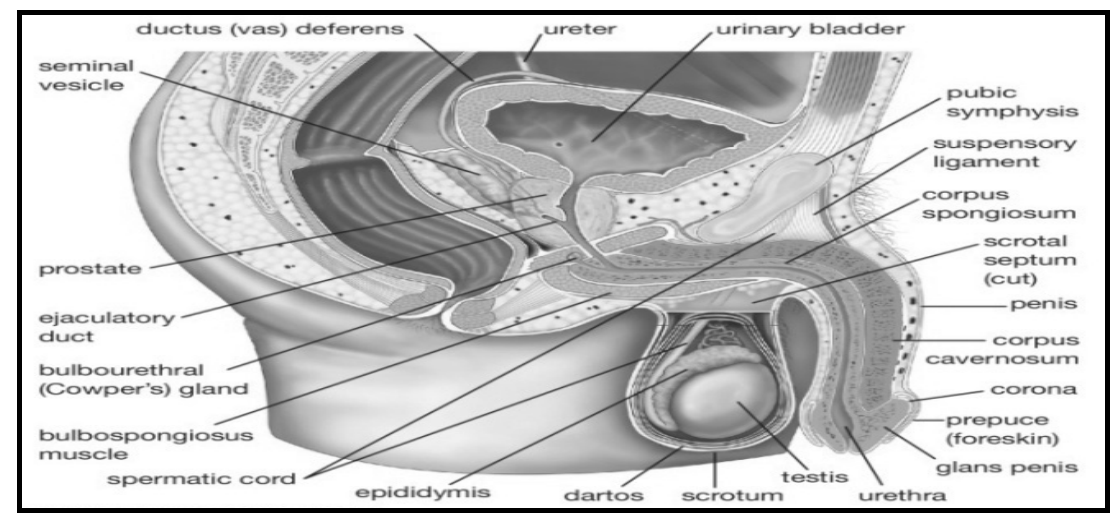

Figure No.1: Male Reproductive System

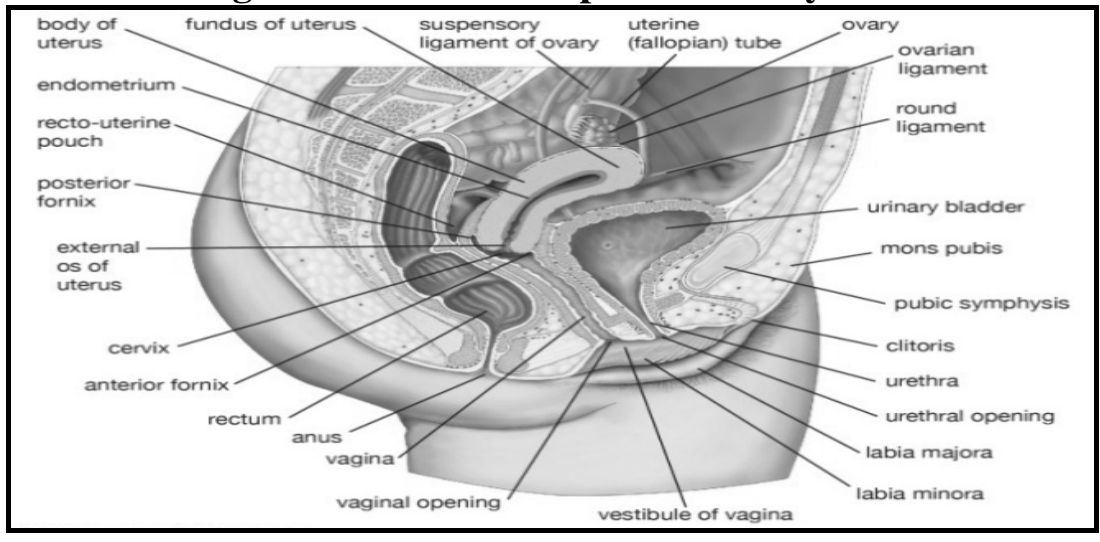

Figure No.1: Female Reproductive System

\section{CONCLUSION}

In conclusion, it is clear that therapeutic plants assume a significant job as antifertility specialists. Despite of various commercially available oral contraceptives inside the market, natural antifertility sellers suggests promising output by minimizing the number of adverse drug properties. Current research toward conventional medicinal drug is developing swiftly due to its safety and much less price consumption.

\section{ACKNOWLEDGEMENT}

The authors wish to express their sincere gratitude to School of Pharmacy, Sri Balaji Vidyapeeth Deemed University, Pillayarkuppam, Puducherry, India for providing necessary facilities to carry out this research work.

\section{CONFLICT OF INTEREST}

We declare that we have no conflict of interest.

\section{REFERENCES}

1. Shaik R S Kanhere, Cuddapah R, Nelson K S, Vara P R, Sibyala S. Antifertility activity of Artemisia vulgaris leaves on female wistar rats, Chin J Nat Med, 12(3), 2014, 180-185.

2. Shibeshi W, Makonne E, Zerihum L, Debella A. Effect of Achyranthes aspera L. on fetal abortion, uterine and pituitary weights, serum lipids and hormones, Afr Health Sci, 6(2), 2006, 108-112.

3. Khushalani $H$, Tatke $P$, Singh $K \mathrm{~K}$. Antifertility activity of dried flowers of Wood for dia fruticosa kurz, Indian J Pharm Sci, 68(4), 2006, 528-529.

4. United nations World population prospects, The revision, and Executive summary, Department of economic and social affairs population division, New York, 2007, 1-21. 
Pradeep Raj D and Irisappan Sarathchandiran. / International Journal of Research in Pharmaceutical and Nano Sciences. 9(1), $2020,27-32$.

5. Vaidya P, Padmashali S, Vagdevi H M, Sathyanarayana N D, Antifertility effect of the plant Balanites roxburghii (Balanitaceae) in female rats, Indian $J$ Pharm Sci, 68(3), 2006, 347-351.

6. Jain S, Jain A, Paliwal P, Solanki S S. Antifertility effect of chronically administered Tabernaemontana divaricata leaf extract on male rats, Asian Pac J Trop Med, 5(7), 2012, 547-551.

7. Bent S, Ko R. Commonly used herbal medicines in the United States: A review, Am J Med, 116(7), 2004, 478-485.

8. Chowdhury S R, Gupta C M, Kamboj V P. Current status in fertility regulation: Indigenous and modern approaches, Central Drug Research Institute, Lucknow, 2001.

9. Allag I S, Rangari K. Extra genomic action of steroids on spermatozoa, Prospects for regulation of fertility, Health Popul, 25(1), 2002, 38-44.

10. Montaserti A, Pourheydar M, Khazaei M, Ghorbani R. Anti-fertility effects of Physalis alkekengi alcoholic extract in female rat, Iran J Reprod Med, 5(1), 2007, 13-16.

11. Mahadevan, Harold Ellis, Vishy. Clinical anatomy applied anatomy for students and junior doctors, Chichester, West Sussex, Wiley-Blackwell, $U K$,

ISBN 9781118373767, $13^{\text {th }}$ Edition, 2013.

12. Lemke T L, Williams D A, Roche V F, Zito $\mathrm{S}$ W. Foye's principles of medicinal chemistry, Wolters Kluwer/Lippincott Williams and Wilkins, New Delhi, $6^{\text {th }}$ Edition, 2008, 1377.

13. Shah G M, Khan M A, Ahmad M, Zafar M, Khan A A, Observations on antifertility and abortifacient herbal drugs, Afr J. Biotech, 8(9), 2009, 1959-1964.

14. Kamboj V P, Dhawan B N. Research on plants for fertility regulation in India, $J$. Ethnopharmacol, 6(2), 1982, 191-193.

15. Pokharkar R D, Saraswat R K, Kotkar S. Survey of plants having antifertility activity from Western Ghat area of Maharashtra

Available online: www.uptodateresearchpublication.com
State, J. Herb Med Toxicol, 4(2), 2010, 7175.

16. Kaur R, Sharma A, Kumar R, Kharb R. Rising Trends towards herbal contraceptives, J. Nat Prod Plant Resour, 1(4), 2011, 5-12.

17. Gupta R S, Kumar P, Dixit V P, Dhobhal M P. Antifertility studies of root extract of the Barleria prionitis Linn in male albino rats with special reference to testicular cell population dynamics, J. Ethnopharmacol, 70(2), 2000, 111-117.

18. Dixit V P, Agarwal M, Bhargava S K, Gupta R S, Jain G C. Effects of Butea monosperma seed extract fraction (Butin) on testicular function of rats, dogs and presbytis monkey, Lugoslav Physiol Pharmacol Acta, 17(3), 1981, 151-162.

19. Yadav R, Jain G C. Antifertility effect of aqueous extract of seeds of Cassia fistula in female rats, Adv Contracept, 15(4), 1999, 293-301.

20. Das R P, Effect of papaya seeds on the genital organs and fertility of male rats, Indian J. Exp Biol, 18(4), 1980, 408-409.

21. Bidwai P P, Wangoo D, Bhullar N. Antispermatogenic action of Cleastrus paniculatus seed extract in the rat with reversible changes in the liver, $J$. Ethnopharmacol, 28(3), 1990, 293-303.

22. Garg S K. Antifertility effect of some chromatographic fractions of Daucus carota, Ind J. Pharmacol, 7(1), 1975, 40-42.

23. Bhatnagar U. Postcoital contraceptive effects of an alcoholic extract of the Daucus carota Linn seed in Rats, Clin Drug Investig, 9(1), 1995, 30-36.

24. Bourdy G, Walter A. Maternity and medicinal plants in Vanuatu I. the cycle of reproduction, J. Ethnopharmacol, 37(3), 1992, 179-196.

25. Brondegaard V J. Contraceptive plant drugs, Planta med, 23(2), 1973, 167-172.

26. Vasudeva N, Sharma S K, Post-coital antifertility activity of Hibiscus rosasinensis

January - February

31 
Pradeep Raj D and Irisappan Sarathchandiran. / International Journal of Research in Pharmaceutical and Nano Sciences. 9(1), $2020,27-32$.

Linn. Roots, Evid Based Complement Alternat Med, 5(1), 2008, 91-94.

27. Pradeepa M. S, Gouda V, Singh S, Chetana $\mathrm{H}$, Shambhulingaiah H M, Ramda M. Antifertility effect of Indigofera linnaeiali in female albino rats, Int. J. Phytopharmacol, 3(1), 2012, 42-49.

28. Saalu L C. Nigerian folklore medicinal plants with potential antifertility activity in males, A scientific appraisal, Res J Med Plant, 10(3), 2016, 201-227.

29. Keshri G, Singh M M, Lakshmi V, Kamboj V P. Post-coital contraceptive efficacy of the seeds of Nigella sativa in rats, Indian $J$ Physiol Pharmacol, 39(1), 1995, 59-62.

30. Najafizadeh P, Dehghani F, Panjeh Shahin $\mathrm{M}$, Hamzei and Taj S. The effect of a hydroalcoholic extract of olive fruit on reproductive argons in male Sprague dawley rats, Iran J Reprod Med, 11(4), 2013, 293300.

31. Lakshmi V P, Kumar R, Agarwal S K, Dhar J D. Antifertility activity of Piper longum Linn in female rats, Nat Prod Res, 20(3), 2006, 235-239.

32. Verma O P, Kumar S, Chatterjee S N. Antifertility effects of common edible Portulaca oleracea on the reproductive organs of male albino mice, Indian J Med Res, 75, 1982, 301-310.

33. Makonnen E, Zerihun L, Assefa G, Rostom A A. Antifertility activity of Ricinus communis seed in female guinea pigs, East Afr Med J, 76(6), 1999, 335-337.

34. Gandhi M, Lal R, Sankaranarayanan A, Sharma P L. Post-coital antifertility activity of Ruta graveolens in female rats and hamsters, J. Ethnopharmacol, 34(1), 1991, 49-59.
35. Al-Hamood M H, Elbetieha A, Alkofahi A, Bataineh H. Reproductive toxicity potentials of Salvia fruticosa (Labiatae) in rats, J. Ethnopharmacol, 61(1), 1998, 67-74.

36. Garg S K. Antifertility screening of plant, Investigation on Taxus baccata Linn. Leaves, Indian J. Med Res, 60(1), 1997, 159-163.

37. Kassem A, Al-Aghbari A, AL-Habori M, Al Mamary M. Evaluation of the potential antifertility effect of fenugreek seeds in male and female rabbits, Contraception, 73(3), 2006, 301-306.

38. Menkovic N, Savikin K, Tasic S, Zdunic G, Stesevic D, Milosavljevic S, Vincek D. Ethnobotanical study on traditional uses of wild medicinal plants in Prokletije Mountains (Montenegro), J. Ethnopharmacol, 133(1), 2011, 97-107.

39. Bhargava S K. Antiandrogenic effects of a flavonoid-rich fraction of Vitex negundo seeds: A histological and biochemical study in dogs, J. Ethnopharmacol, 27(3), 1989, 327-339.

40. Duke J A, Du Cellier J L. Duke's Handbook of medicinal plants of the bible, CRC Press, $1^{\text {st }}$ Edition, 2008, 126-135.

41. Nadkarni K M. Indian Material Medica Mumbai: Popular Prakashan, 1, 750, 1993, 1276-1277.

42. Mahajan R T, Chopda M Z. Phytopharmacology of Ziziphus jujuba MillA plant review, Phcog Rev, 3(6), 2009, 320329.

Please cite this article in press as: Pradeep Raj D and Irisappan Sarathchandiran. A review on antifertility activity of medicinal plants, International Journal of Research in Pharmaceutical and Nano Sciences, 9(1), 2020, 27-32. 